\title{
ASSESSMENT OF THE EFFECTS OF BUILDING COLLAPSE RISKS ON THE STAKEHOLDERS IN THE NIGERIAN BUILT ENVIRONMENT
}

\author{
D. Obodoh ${ }^{1, *}$, B. Amade ${ }^{2}$, C. Obodoh ${ }^{3}$ and C. Igwe ${ }^{4}$ \\ 1, DEPARTMENT OF BUILDING, NNAMdi AZIKIWE UNIVERSITY AWKA, ANAMBRA STATE, NIGERIA \\ 2, Dept. of Project Management TeChnology, Fed. Univ. Of TeChnology, OWerri, Imo State, NIGERIA \\ 3, Dept. Of Estate Management, Enugu State Univ. Of SCience \& TeCh., Enugu, EnUgu State, NIGERIA \\ 4, Department of Estate Management, NNAmdi AZikiwe University AWKa, ANAmbra State, NIGERIA
}

\section{Email addresses: ${ }^{1}$ da.obodoh@unizik.edu.ng, 2 amadebenedict@futo.edu.ng, 3 chika.obodoh@yahoo.com, 4 cp.igwe@unizik.edu.ng}

\begin{abstract}
The study investigates the effects of building collapse risks on the stakeholders in the Nigerian built environment. Survey research design was adopted in carrying out the research and five cities in Nigeria were selected (Abuja, Ibadan, Port Harcourt, Owerri and Lagos). The target population for the study is the stakeholders in the Nigerian built environment: key professionals in the construction industry, clients/developers and users of the finished product. A sample size of 1999 was chosen using Taro Yamane method. The data generated from 1860 respondents representing $93 \%$ of the distributed questionnaires were presented using frequency tables, pie -charts and bar charts, while analysis was done using percentages and weighted mean. The findings of the study show that building collapse risks have multifarious factors which were categorized as Economic/Financial risks, Socio-political risks, Human related risks, Physical risks, Environmental risks and Law/legal risks. The negative effects of these risks are: loss of property, loss of reputation and integrity of the contractors, loss of lives, legal tussle among the stakeholders, etc.. It was also found out that economic/financial risks have the predominant effect on the stakeholders, followed by Human related risks, Socio-Political risks, Physical risks, Environmental risks and lastly Law/Legal risks. It was recommended that all hands should be on deck to curb the havoc caused by building collapse as the effect is usually felt by all and sundry. There should be adequate funding and monitoring of the activities of all Emergency Management Agencies.
\end{abstract}

Keywords: Building collapse, Building collapse risks, Stakeholders, Built Environment, Millennium Developments Goals (MDGs), Emergency Management Agency.

\section{INTRODUCTION}

Building collapse is a phenomenon characterized by the compromise in the structural integrity of a building's component elements, resulting in its eventual failure. Structural failure refers to the loss of load carrying capacity of a structural component or structure itself, that is failure of the structural component to perform as designed [1]. This failure in many cases renders the building unsafe for habitation or continuation of construction activities and could eventually lead to collapse, damage to property and loss of lives. Building collapse risk can be described as an event or action that could cause negative impacts or consequences on the building users, investors, stakeholders and the general public, and hence affect the project objectives. From this perspective, building collapse risks can be observed as "threats to success" [2]

In the pre-colonial period, building construction was carried out by our fore fathers with local building materials and the type of buildings prevalent within the period are mud houses, with thatched roofs.

${ }^{*}$ Corresponding author, tel: +234 - $803-755-5599$ 
Within this period, there were no sophisticated and complex buildings like block of flats, massionettes, high-rise buildings etc. What was obtainable were bungalows hence, there were no recorded cases of building collapse.

In the post-colonial period especially within the period of oil boom (1970s), the building construction industry witnessed a boom and many building construction projects were carried out. During this period also, improvements in the technological know-how, economic development and industrialization led to the improvement in the building construction processes and procedure. The sophisticated nature and complexity in modern building designs introduced various lines of risks in building development process instead of eliminating or removing them. These new designs and technology associated with different types of risks could lead to building failures, abandonment and collapse. Hence, from the period of oil boom to the present day, Nigeria has witnessed many cases of building collapse in different parts of the country. The frequency of building collapse in Nigeria in recent past has become a major issue and concern in her economic ratings [3]. The spate and frequency of occurrence has become major source of concern not only to the government but to all well-meaning Nigerians and stakeholders in the building industry.

Previous researches show that there were spikes in the reported cases of building collapse in Nigeria in the years 1985, 1995, 1999, and 2005, and also suggests an upward trend in the number of cases of building collapse in the year 2010 [4]. The Council of Registered Builders of Nigeria [5] identified 104 incidences of building collapse based on available records in Nigeria spanning from 1974 - 2016. These observations are astonishing and most worrying.

In order to tackle the cases of building collapse and the associated risks, the Nigerian government at different periods made Laws to guide the building development to curb the menace and risks associated with building collapse. In 1992, the government enacted the Nigerian Urban and Regional Planning Act No. 88 of 1992 to facilitate the preparation and implementation of development plans and planning scheme with a view of establishing a better environment for living, working and recreation. Apart from the above general aim, the Act was also meant to give more seriousness to development control among other specific objectives.

The government also established the disaster management agencies for the purpose of managing disasters in Nigeria such as fire, building collapse, flooding, landslides, etc. These agencies include National Emergency Management Agency (NEMA), Nigeria Fire Service, Red Cross Society, etc. The federal government has a mandate to assist state and local governments in disaster response and recovery by establishing State Emergency Management Agency (SEMA) in all the states of the federation and the Federal Capital Territory, Abuja. The states are in turn mandated to establish Local Emergency Management Agency (LEMA) in all the local government areas of the respective state. The functions of NEMA include: Formulation of policy related to disaster management in Nigeria, monitors state of preparedness against disaster, provision of relieve materials to disaster victims in Nigeria, guides and educates against sudden disaster in Nigeria, trains and undertakes human capacity development, takes delivery of critical rescue equipment for emergencies, etc. According to [6], an appraisal of the effectiveness of the disaster management agencies in Nigeria is not far-fetched. He established the following in his study :(i) There are lots of bureaucratic bottlenecks in obtaining emergency assistance. (ii) NEMA's activities are limited to urban centers, where the Headquarters or Zonal offices are situated. (iii) Most or even all the states have no functional LEMA. (iv) NEMA and indeed SEMA are constantly denied financial support to be effective in their operation.

Also in 2018, the Federal Republic of Nigeria announced a new National Building Code that will regulate construction with the aim of improving on measures to safeguard lives and property in the country. This has not yielded the desired result as most states in the country have not passed the Urban and Regional Planning Law to make the new National Building Code operational in their respective states. Building code is a set of legal requirements of which the purpose is to promote good practice in design, construction and maintenance of buildings in the interest of the health, safety and welfare of people using the buildings. The code sets out the basic requirements for the design and construction of building which represents a code of good building practice.

In spite of the above efforts to forestall the cases of building collapse and attendant risks by the Federal government and professionals in the building industry, not enough appears to be done, as this phenomenon appears to be on the rise [1], hence the need for this study. 


\section{LITERATURE REVIEW}

The collapse of a building has tremendous effects that cannot be easily forgotten by any of its victims. The consequences are usually in the form of economic and social implications, and they include loss of human lives, injuries, economic waste in terms of loss of properties, investments, jobs, incomes, loss of trust, dignity and exasperation of crises among the stakeholders and environmental disaster [7].

The complete quantification of the effects of any collapse is extremely difficult, as there are so many factors involved which include emotional and subjective factors. Apart from the number of deaths that can often be truly identified, the rest of the effects are surrounded by so many uncertainties which make analysis only approximate. Putting aside the quantifiable economic sums, the stress, trauma and shocks may have far-reaching effects upon the building owner and /or employees, occupants and others involved in one way or the other with the structure [7]. More so, various site of building collapse scattered across the length and breadth of Nigeria is making the environment unhealthy as such collapsed buildings has become hideout for hoodlums, touts etc. Dangerous animals like snakes have also made such buildings their place of abode, which is a danger. Oke [8] carried out a research on the Causes and Effects of building collapse in Nigeria and identified the following as the consequences of building collapse. Apart from loss of lives (mostly innocent citizens), many other people have been rendered permanently disabled in one form or the other as a result of increasing rate of building collapse. Other consequences include: Economic losses, Loss of countless properties, Creates unhealthy environment, Hideout for hoodlums and places of abode for dangerous animals like snake. Nwafor [9] in his study identified the reputational effects of building collapse on Nigerian building industry to include: de-market of the values and integrity of building professionals, portray Nigerian building industry as being corrupt and professionals' marketability to foreign firms/clients has been devalued. The researcher agrees with [9] on the reputational effect of building collapse on Nigerian construction industry considering the spate of building collapse in Nigeria and the attendant losses. Dimuna [10] stated in his study, that the incidences of building collapse witnessed in the country in the recent years has resulted in the loss of many lives and destruction of properties worth several millions of naira. Many families have been traumatized and many developers have lost their life investments. According to [11], the consequences of building collapse can be summarized as: Loss of lives, Loss of money invested, Material wastage, Loss of prestige of the owner, Loss of reputation of the contractor, Loss of the buildings' aesthetic values, Increase in the cost of maintenance and shortage of manpower.

Adebowale [12] in their study identified that the effects of building collapse are usually in the form of economic and social implications which include: Loss of human life, Loss of materials, Loss of capital investments, Physical damage and psychological trauma. Chendo and Obi [13] identified the following as the consequences of building collapse in Nigeria and they include: loss of life property and huge sum of capital, loss of reputation and integrity leading to psychological trauma, Loss of new commissions and contracts, Withdrawal of practicing licenses and Loss of materials and capital investments.

Janssens, et al [14] in their study on building failure consequences classified the consequences resulting from a building failure into three groups: Economic, Human and Environmental consequences. For the purpose of this study building collapse risks could be classified into six groups: Economic/Financial risks, Socio-Political risks, Human related risks, Environmental risks, Physical risks and Law/Legal risks.

\subsection{Economic/Financial Risks}

Economic/Financial risks can be described as building collapse risks associated with money. These risks include: Loss of property, Loss of annual income/capital investment, Loss of materials, Bankruptcy of the investor/developer, Decrease in the contributions of real estate sector to the nation's GDP, Loss of investment, Increase in the cost of maintenance, Shortage in the supply of real estate facilities, Clean up costs, Rescue costs, Cost of investigation/compensation, Treatment of injured people, Cost of rebuilding/repair, Cost of loss of functionality, Cost of replacement/repair of its contents, Cost of temporary relocation, Regional economic effects, Waste of resources, time and labour, Cost of legal dispute, etc.

\subsection{Socio-Political Risks}

The sub-risks under this category include: Loss of reputation and integrity of the contractors, Psychological trauma and shocks, Loss of new 
commission and contracts, Withdrawal of practicing licenses, Loss of trust, Discourages investment in property development, Loss of jobs, Scarcity of property, Loss of prestige of the owner, Shortage of manpower, De-marketing the values of industry professionals, Portrays Nigeria building industry as being corrupt, Professionals marketability to foreign firms/clients has been devalued, etc.

\subsection{Human Related Risks}

These are building collapse risks that directly affect human beings/human lives. They include: Loss of lives, Injuries, Disruption of educational activities, Loss of contributions from the victims towards the socioeconomic growth of the nation, Increase in death rate against the United Nations Millennium Development Goals (MDGs), Leads the victims to permanent disability, Psychological damage (fear, helplessness, distress, depression and suicides), Disruption of economic activities, etc.

\subsection{Environmental Risks}

The Environmental risks in building collapse consist of: Provides hideout for robbers and hoodlums, Place of abode for dangerous animals like snakes, Environmental damage, Loss of functionality in the neighbourhoods, $\mathrm{CO}_{2}$ Emission/Pollution, Reduction in the energy use, Increase in toxic emission, Environmental studies/repair, Loss of building aesthetic values, Degrading of the environment, etc.

\subsection{Physical Risks}

These are building collapse risks that are often associated with the physical nature of the building that collapsed. They include: Structural damage, Damage to contents, Loss of functionality, Replacement/repair of structure, Replacement/repair of contents, Temporary relocation, Loss of strength of the building, Shortage of manpower, Increment of sick citizens, Street blockage, Evacuation difficulty, Travel distance increment, Damage of materials beyond reuse, Loss of fauna and flora, etc.

\subsection{Law/Legal Risks}

Legal risks associated with building collapse include: Exasperation of crises among stakeholders, Legal tussle among stakeholders, Arbitration/Mediation to resolve crises arising from building collapse, Conflicts resolution, Apportioning blames and arbitrary words of mouth among the stakeholders, etc.

\section{METHODOLOGY}

Survey research design was adopted for the study. The study was carried out in five selected cities in Nigeria and they are Abuja, Ibadan, Lagos, Owerri and Port Harcourt. The study focused on the stakeholders in the built environment. A sample size (1999) of the stakeholders in the selected cities used for the study was determined using the statistical formular for determining sample size for finite population as adopted by Taro Yamane formular. The formular is stated as:

$$
n=\frac{N}{1+N e^{2}}
$$

Where $\mathrm{n}$ is the sample size, $\mathrm{N}$ is total population and e is limit of tolerance error. The value of e used is $5 \%$ $=0.05$.

The data for research were collected through questionnaires and personal observations, and analyzed using Statistical Package for Social Science (SPSS), version 23.

\section{RESULTS AND DISCUSSION}

\subsection{Socio-Economic Characteristics of the Respondents}

From the analysis in Table 1, it shows that 93 percent of the distributed questionnaires were returned while 7 percent of the distributed questionnaires were unreturned. This shows that high percentage of the distributed questionnaire was returned. The above response rate is adjudged high enough to be used and relied upon for data analysis.

Table 1: Distribution and Return of Questionnaires

\begin{tabular}{llll}
\hline $\begin{array}{l}\text { Response } \\
\text { Option }\end{array}$ & $\begin{array}{l}\text { Number } \\
\text { Distributed }\end{array}$ & $\begin{array}{l}\text { Number } \\
\text { Collected }\end{array}$ & Unreturned \\
\hline Professionals & 1231 & $1146(57 \%)$ & $85(4 \%)$ \\
Clients & 384 & $360(18 \%)$ & $24(1 \%)$ \\
Users & 384 & $354(18 \%)$ & $30(2 \%)$ \\
Total & 1999 & $1860(93 \%)$ & $139(7 \%)$ \\
\hline \multicolumn{4}{c}{ Source: Field Survey, 2018 }
\end{tabular}

Figure 2 shows that 2 percent of the respondents are less than 30 years of age, 10 percent are between the age ranges of $31-40$ years, 22 percent are $41-50$ years, 44 percent are within 51-60 years while 21 percent are 61 years and above. The above analysis shows that the majority of the respondents are between the ages of 31 and above. This shows that 
the majority of the respondents is enough to understand the problem of the study and therefore experienced to give adequate answers to the questions.

From the analysis in Figure 3, it shows that 1 percent of the respondents are SSCE/WAEC holders, 11 percent are ND/NCE holders, 66 percent are B.Sc/HND holders, 19 percent are M.Sc holders while 3 percent of the respondents are PhD holders. The analysis shows that most of the respondents are B.Sc/HND holders. Therefore, it could be deduced from the data analysis that the majority (66\%) of the total respondents have educational status of B.Sc/HND and were literate enough to understand and express ideas on the effects of building collapse risks on the stakeholders in the Nigerian built environment and other related issues in the study area.

The analysis in figure 4 above shows that 62 percent of the respondents are professionals, 19 percent clients while 19 percent are users. This shows that majority of the respondents are professionals. Therefore, it could be deduced from the data analysis that the information given by such professionals that form the majority in respondents status could be relied upon for data analysis while that of clients and users will compliment.

Figure 5 shows that 24 percent of the respondents are Architects, 17 percent are Builders, 29 percent of the respondents are Engineers, and 14 percent are Quantity Surveyors while 16 percent of the respondents are Town Planners. This shows that majority of the respondents are Engineers, followed by Architects, Builders, Town Planners and Quantity Surveyors which form the key players in the Built Environment.

The analysis in figure 6 shows that 1 percent of the respondents have work for less than 5 years, 17 percent of the respondents have working experience of $6-10$ years, 36 percent have work for $11-15$ years, 33 percent have working experience of $16-20$ years while 13 percent of the respondents have working experience of 21 years and above.

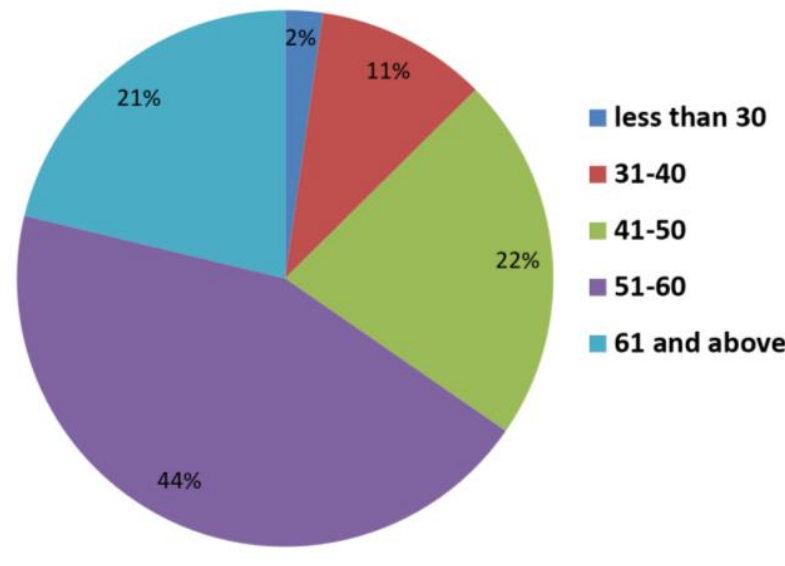

Fig 2: Response on Age

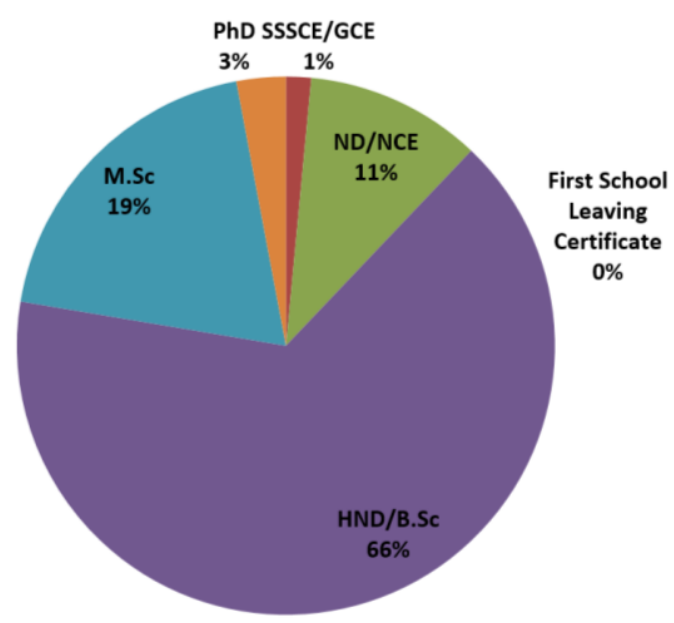

Fig 3: Response on Educational Qualifications

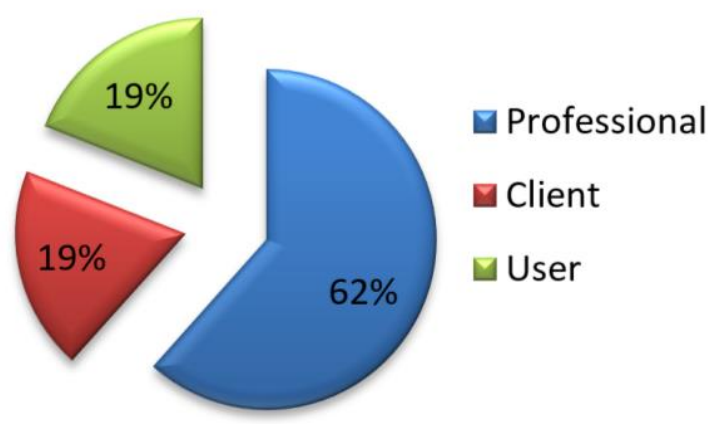

Figure 4: Response on status of respondents

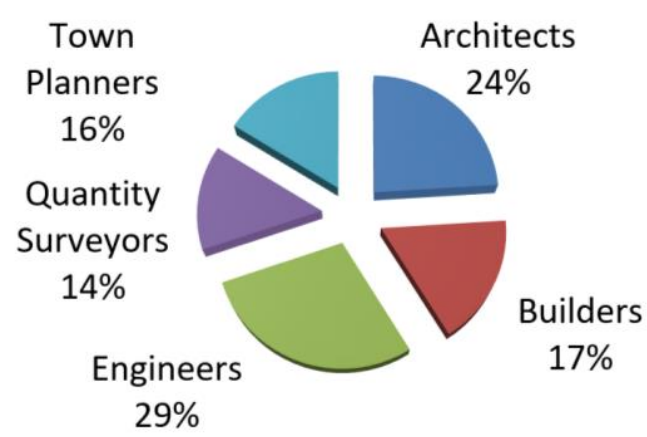

Figure 5: Response on Profession of Respondents 


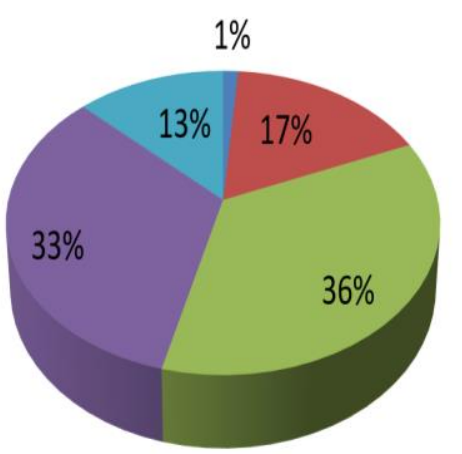

Less than 5 years

- $6-10$ years

$11-15$ years

$16-20$ years

21 years and above

Figure 6: Response on Working Experience
This shows that majority of the respondents have reasonable working experience in construction industry to understand the problem of the study and other related issues. Therefore, the information given could be used and relied upon for data analysis.

\subsection{Effect of Building Collapse Risks on the Stakeholders in the Nigerian Built Environment}

In your own opinion, state the extent of agreement on the effect of the following building collapse risks on the stakeholders. $\quad \mathrm{SA}=$ Strongly agree (5), $\mathrm{A}=$ Agree (4), $U=$ Undecided (3), $D=$ Disagree (2), $\mathrm{SD}=$ Strongly disagree (1).

Table 2: Response on the effect of building collapse risks on the stakeholders in Nigerian built environment

\begin{tabular}{|c|c|c|c|c|c|c|c|c|}
\hline $\mathrm{S} / \mathrm{NO}$ & Economic/Financial Risks & SA & A & $U$ & $\mathrm{D}$ & SD & Mean & Rank \\
\hline 1. & Loss of property & $1612(87 \%)$ & $186(10 \%)$ & $31(2 \%)$ & $31(2 \%)$ & 0 & 8.12 & 1 st \\
\hline 2 & $\begin{array}{l}\text { Loss of annual income/capital } \\
\text { investment }\end{array}$ & $1178(63 \%)$ & $558(30 \%)$ & $62(3 \%)$ & $62(3 \%)$ & 0 & 6.37 & $4^{\text {th }}$ \\
\hline 3 & Loss of materials & $1240(67 \%)$ & $465(25 \%)$ & $62(3 \%)$ & $93(5 \%)$ & 0 & 6.72 & $2^{\text {nd }}$ \\
\hline 4 & $\begin{array}{l}\text { Bankruptcy of investor or } \\
\text { developer }\end{array}$ & $465(25 \%)$ & $868(47 \%)$ & $372(20 \%)$ & $155(8 \%)$ & 0 & 4.21 & $17^{\text {th }}$ \\
\hline 5 & $\begin{array}{l}\text { Decrease in the contributions of } \\
\text { real estate sector to the nation's } \\
\text { GDP }\end{array}$ & $558(30 \%)$ & $1054(57 \%)$ & $186(10 \%)$ & $124(7 \%)$ & 0 & 4.40 & $15^{\text {th }}$ \\
\hline 6 & Loss of life investment & $713(38 \%)$ & $744(40 \%)$ & $279(40 \%)$ & $124(7 \%)$ & 0 & 4.9 & $7^{\text {th }}$ \\
\hline 7 & $\begin{array}{l}\text { Increase in the cost of } \\
\text { maintenance }\end{array}$ & $434(23 \%)$ & $868(47 \%)$ & $248(13 \%)$ & $217(11 \%)$ & $93(5 \%)$ & & \\
\hline 8 & $\begin{array}{l}\text { Shortage in the supply of real } \\
\text { estate facilities }\end{array}$ & $589(32 \%)$ & $744(40 \%)$ & $155(8 \%)$ & $310(16 \%)$ & $62(3 \%)$ & 4.50 & $14^{\text {th }}$ \\
\hline 9 & Clean up costs & $589(32 \%)$ & $837(45 \%)$ & $310(16 \%)$ & $93(5 \%)$ & $31(2 \%)$ & 4.53 & $13^{\text {th }}$ \\
\hline 10 & Rescue costs & $589(32 \%)$ & $868(47 \%)$ & $279(15 \%)$ & $124(7 \%)$ & 0 & 4.55 & $12^{\text {th }}$ \\
\hline 11 & $\begin{array}{l}\text { Cost of } \\
\text { investigation/compensation }\end{array}$ & $651(35 \%)$ & $930(50 \%)$ & $217(12 \%)$ & $62(3 \%)$ & 0 & 4.77 & $9^{\text {th }}$ \\
\hline 12 & Treatment of injured people & $620(33 \%)$ & $1054(57 \%)$ & $186(10 \%)$ & 0 & 0 & 4.71 & $10^{\text {th }}$ \\
\hline 13 & Cost of rebuilding/repair & $1054(57 \%)$ & $713(37 \%)$ & $93(5 \%)$ & 0 & 0 & 6.09 & $5^{\text {th }}$ \\
\hline 14 & Cost of loss of functionality & $403(22 \%)$ & $1116(60 \%)$ & $341(18 \%)$ & 0 & 0 & 4.02 & $19^{\text {th }}$ \\
\hline 15 & $\begin{array}{l}\text { Cost of replacement/repair of its } \\
\text { contents }\end{array}$ & $682(36 \%)$ & $899(48 \%)$ & $217(11 \%)$ & $62(3 \%)$ & 0 & 4.81 & $8^{\text {th }}$ \\
\hline 16 & Cost of temporary relocation & $620(33 \%)$ & $961(52 \%)$ & $217(11 \%)$ & $62(3 \%)$ & 0 & 4.70 & $11^{\text {th }}$ \\
\hline 17 & Regional economic effects & $558(30 \%)$ & $899(48 \%)$ & $248(13 \%)$ & $124(7 \%)$ & $31(2 \%)$ & 4.37 & $16^{\text {th }}$ \\
\hline 18 & $\begin{array}{l}\text { Waste of resources, time and } \\
\text { labour }\end{array}$ & $1209(65 \%)$ & $465(25 \%)$ & $155(8 \%)$ & 0 & $31(2 \%)$ & 6.64 & $3^{\text {rd }}$ \\
\hline \multirow[t]{2}{*}{19} & Cost of legal dispute & $775(42 \%)$ & $806(43 \%)$ & $217(12 \%)$ & $62(3 \%)$ & 0 & 5.10 & $6^{\text {th }}$ \\
\hline & Socio-Political Risks & SA & $A$ & $U$ & $\mathrm{D}$ & SD & Mean & Rank \\
\hline 1 & $\begin{array}{l}\text { Loss of reputations and integrity } \\
\text { of the contractors }\end{array}$ & $1488(80 \%)$ & $217(12 \%)$ & $93(5 \%)$ & $62(3 \%)$ & 0 & 7.92 & $1^{\text {st }}$ \\
\hline 2 & $\begin{array}{l}\text { Psychological trauma and } \\
\text { shocks }\end{array}$ & $1240(67 \%)$ & $434(23 \%)$ & $124(7 \%)$ & $62(3 \%)$ & 0 & 6.68 & $2^{\text {rd }}$ \\
\hline
\end{tabular}


ASSESSMENT OF THE EFFECTS OF BUILDING ColLAPSE RISKS ON THE STAKEHOLDERS IN THE NIGERIAN BUILT ENVIRONMENT, D. Obodoh, et. al

\begin{tabular}{|c|c|c|c|c|c|c|c|}
\hline 3 & $\begin{array}{l}\text { Loss of new commission and } \\
\text { contracts }\end{array}$ & $682(37 \%)$ & $713(38 \%)$ & $341(18 \%)$ & $93(5 \%)$ & $31(2 \%)$ & 5.58 \\
\hline 4 & $\begin{array}{l}\text { Withdrawal of practicing } \\
\text { licenses }\end{array}$ & $775(42 \%)$ & $620(33 \%)$ & $217(12 \%)$ & $124(7 \%)$ & $124(7 \%)$ & 5.71 \\
\hline 5 & Loss of trust & $930(50 \%)$ & $682(37 \%)$ & $186(10 \%)$ & $62(3 \%)$ & 0 & 6.31 \\
\hline 6 & $\begin{array}{l}\text { Discourages investment in } \\
\text { property development }\end{array}$ & $496(27 \%)$ & $775(42 \%)$ & $248(13 \%)$ & $217(12 \%)$ & $124(7 \%)$ & 4.98 \\
\hline 7 & Loss of jobs & $620(33 \%)$ & $713(38 \%)$ & $217(12 \%)$ & $217(12 \%)$ & $93(5 \%)$ & 5.43 \\
\hline 8 & Scarcity of property & $434(23 \%)$ & $775(42 \%)$ & $248(12 \%)$ & $310(17 \%)$ & $93(5 \%)$ & 4.79 \\
\hline 9 & Loss of prestige of the owner & $589(32 \%)$ & $651(35 \%)$ & $372(20 \%)$ & $186(10 \%)$ & $62(3 \%)$ & 5.21 \\
\hline 10 & Shortage of manpower & $217(12 \%)$ & $465(25 \%)$ & $465(25 \%)$ & $434(23 \%)$ & $279(15 \%)$ & 4.24 \\
\hline 11 & $\begin{array}{l}\text { De-marketing the values of } \\
\text { industry professionals }\end{array}$ & $434(23 \%)$ & $837(45 \%)$ & $279(15 \%)$ & $217(12 \%)$ & $93(5 \%)$ & 4.86 \\
\hline 12 & $\begin{array}{l}\text { Portrays the Nigeria building } \\
\text { industry as being corrupt }\end{array}$ & $806(43 \%)$ & $589(32 \%)$ & $341(18 \%)$ & $93(5 \%)$ & $31(2 \%)$ & 5.83 \\
\hline 13 & $\begin{array}{l}\text { Professionals' marketability to } \\
\text { Foreign firms /clients are } \\
\text { devalued }\end{array}$ & $1116(60 \%)$ & $465(25 \%)$ & $186(10 \%)$ & $93(5 \%)$ & 0 & 6.55 \\
\hline
\end{tabular}

\begin{tabular}{|c|c|c|c|c|c|c|c|c|}
\hline & Human Related Risks & SA & $A$ & $U$ & $\mathrm{D}$ & SD & Mean & Rank \\
\hline 1 & Loss of lives & $1395(75 \%)$ & $372(20 \%)$ & $62(3 \%)$ & $31(2 \%)$ & 0 & 7.64 & 1 st \\
\hline 2 & Injuries & $1271(68 \%)$ & $558(30 \%)$ & 0 & $31(2 \%)$ & 0 & 7.00 & $2^{\text {nd }}$ \\
\hline 3 & $\begin{array}{l}\text { Disruption of educational } \\
\text { activities }\end{array}$ & $155(8 \%)$ & $868(47 \%)$ & $279(16 \%)$ & $372(20 \%)$ & $186(10 \%)$ & 4.00 & $8^{\text {th }}$ \\
\hline 4 & $\begin{array}{l}\text { Loss of the contribution from the } \\
\text { victims towards the socio- } \\
\text { economic growth of the nation }\end{array}$ & $434(23 \%)$ & $837(45 \%)$ & $279(15 \%)$ & $217(12 \%)$ & $93(5 \%)$ & 5.20 & $6^{\text {th }}$ \\
\hline 5 & $\begin{array}{l}\text { Increase in death rate against } \\
\text { the United Nations Millennium } \\
\text { Development Goals (MDGs) }\end{array}$ & $403(22 \%)$ & $930(50 \%)$ & $279(15 \%)$ & $186(10 \%)$ & $62(3 \%)$ & 4.90 & $7^{\text {th }}$ \\
\hline 6 & $\begin{array}{l}\text { Leads the victims to permanent } \\
\text { disability }\end{array}$ & $775(42 \%)$ & $589(32 \%)$ & $341(18 \%)$ & $93(5 \%)$ & $62(3 \%)$ & 5.89 & $4^{\text {th }}$ \\
\hline 7 & $\begin{array}{l}\text { Psychological damage (fear, } \\
\text { helplessness, distress, } \\
\text { depression and suicides) }\end{array}$ & $806(43 \%)$ & $806(43 \%)$ & $155(8 \%)$ & $93(5 \%)$ & 0 & 6.44 & $3^{\text {rd }}$ \\
\hline 8 & Disruption of economic activities & $465(25 \%)$ & $1023(55 \%)$ & $124(6 \%)$ & $217(12 \%)$ & $31(2 \%)$ & 5.31 & $5^{\text {th }}$ \\
\hline & Environmental Risks & SA & A & $U$ & $\mathrm{D}$ & SD & Mean & Rank \\
\hline 1 & $\begin{array}{l}\text { Provides hideouts for robbers } \\
\text { and hoodlums }\end{array}$ & $620(33 \%)$ & $868(47 \%)$ & $186(10 \%)$ & $186(10 \%)$ & 0 & 5.51 & $4^{\text {th }}$ \\
\hline 2 & $\begin{array}{l}\text { Place of abode for dangerous } \\
\text { animals like snakes }\end{array}$ & $868(47 \%)$ & $806(43 \%)$ & $155(8 \%)$ & $93(5 \%)$ & 0 & 6.02 & 1 st \\
\hline 3 & Environmental damage & $651(35 \%)$ & $930(50 \%)$ & $124(6 \%)$ & $124(6 \%)$ & $62(3 \%)$ & 5.70 & $3^{\text {rd }}$ \\
\hline 4 & $\begin{array}{l}\text { Loss of functionality in the } \\
\text { neighborhoods }\end{array}$ & $434(23 \%)$ & $899(48 \%)$ & $279(15 \%)$ & $186(10 \%)$ & $62(3 \%)$ & 5.12 & $6^{\text {th }}$ \\
\hline 5 & $\mathrm{CO}_{2}$ Emissions/Pollution & $341(18 \%)$ & $527(28 \%)$ & $434(23 \%)$ & $465(25 \%)$ & $93(5 \%)$ & 4.39 & $8^{\text {th }}$ \\
\hline 6 & Reduction in the energy use & $279(15 \%)$ & $589(32 \%)$ & $465(23 \%)$ & $341(18 \%)$ & $186(10 \%)$ & 4.24 & $9^{\text {th }}$ \\
\hline 7 & Increase in toxic emission & $186(186 \%)$ & $682(37 \%)$ & $496(27 \%)$ & $310(17 \%)$ & $186(10 \%)$ & 4.01 & $10^{\text {th }}$ \\
\hline 8 & Environmental studies/repair & $403(21 \%)$ & $682(37 \%)$ & $434(23 \%)$ & $279(15 \%)$ & $62(3 \%)$ & 5.00 & $7^{\text {th }}$ \\
\hline 9 & Loss of building aesthetic values & $589(32 \%)$ & $899(48 \%)$ & $155(8 \%)$ & $124(6 \%)$ & $93(5 \%)$ & 5.31 & $5^{\text {th }}$ \\
\hline 10 & Degrading of the environment & $651(35 \%)$ & $961(52 \%)$ & $155(8 \%)$ & $62(3 \%)$ & $31(2 \%)$ & 5.78 & $2^{\text {nd }}$ \\
\hline
\end{tabular}




\begin{tabular}{|c|c|c|c|c|c|c|c|c|}
\hline & Physical Risks & SA & A & U & D & SD & Mean & Rank \\
\hline 1 & Structural damage & $1240(67 \%)$ & $465(25 \%)$ & $155(8 \%)$ & 0 & 0 & 6.72 & $1^{\text {st }}$ \\
\hline 2 & Damage to contents & $899(48 \%)$ & $930(50 \%)$ & $31(2 \%)$ & 0 & 0 & 5.31 & $2^{\text {nd }}$ \\
\hline 3 & Loss of functionality & $651(35 \%)$ & $1085(58 \%)$ & $124(6 \%)$ & 0 & 0 & 5.20 & $5^{\text {th }}$ \\
\hline 4 & Replacement/repair of structure & $837(45 \%)$ & $713(38 \%)$ & $248(13 \%)$ & $62(3 \%)$ & 0 & 5.28 & $3^{\text {rd }}$ \\
\hline 5 & Replacement/repair of contents & $589(32 \%)$ & $806(43 \%)$ & $279(15 \%)$ & $186(10 \%)$ & 0 & 4.86 & $8^{\text {th }}$ \\
\hline 6 & Temporary relocation & $620(33 \%)$ & $868(47 \%)$ & $341(18 \%)$ & $31(2 \%)$ & 0 & 4.91 & $7^{\text {th }}$ \\
\hline 7 & Loss of strength of the building & $806(43 \%)$ & $620(33 \%)$ & $155(8 \%)$ & $124(6 \%)$ & $155(8 \%)$ & 5.24 & $4^{\text {th }}$ \\
\hline 8 & Shortage of manpower & $341(18 \%)$ & $651(35 \%)$ & $434(23 \%)$ & $186(10 \%)$ & $248(13 \%)$ & 4.58 & $11^{\text {th }}$ \\
\hline 9 & Increment of sick citizens & $248(13 \%)$ & $682(37 \%)$ & $434(23 \%)$ & $372(20 \%)$ & $124(6 \%)$ & 4.32 & $12^{\text {th }}$ \\
\hline 10 & Street blockage & $341(18 \%)$ & $837(45 \%)$ & $465(25 \%)$ & $186(10 \%)$ & $31(2 \%)$ & 4.62 & $10^{\text {th }}$ \\
\hline 11 & Evacuation difficulty & $620(33 \%)$ & $930(50)$ & $155(5 \%)$ & $124(6 \%)$ & $31(2 \%)$ & 4.99 & $6^{\text {th }}$ \\
\hline 12 & Travel distance increment & $248(13 \%)$ & $620(33 \%)$ & $589(32 \%)$ & $310(17 \%)$ & $93(5 \%)$ & & $13^{\text {th }}$ \\
\hline 13 & $\begin{array}{l}\text { Damage of materials beyond re- } \\
\text { use }\end{array}$ & $496(27 \%)$ & $868(47 \%)$ & $341(18 \%)$ & $124(6 \%)$ & $31(2 \%)$ & 4.70 & $9^{\text {th }}$ \\
\hline \multirow[t]{2}{*}{14} & Loss of fauna and flora & $155(8 \%)$ & $806(43 \%)$ & $341(18 \%)$ & $372(20 \%)$ & $186(10 \%)$ & 4.01 & $14^{\text {th }}$ \\
\hline & Law/Legal Risks & SA & A & $U$ & $\mathrm{D}$ & SD & Mean & Rank \\
\hline 1 & $\begin{array}{l}\text { Exasperation of crises among } \\
\text { stakeholders }\end{array}$ & $775(42 \%)$ & $806(43 \%)$ & $155(8 \%)$ & $124(6 \%)$ & 0 & 5.20 & $3^{\text {rd }}$ \\
\hline 2 & $\begin{array}{l}\text { Legal tussle among } \\
\text { stakeholders }\end{array}$ & $837(45 \%)$ & $806(43 \%)$ & $155(5 \%)$ & $62(3 \%)$ & 0 & 5.45 & $1^{\text {st }}$ \\
\hline 3 & $\begin{array}{l}\text { Arbitration/Mediation to resolve } \\
\text { crises arising from building } \\
\text { collapse }\end{array}$ & $744(40 \%)$ & $837(45 \%)$ & $186(10 \%)$ & $93(5 \%)$ & 0 & 5.15 & $4^{\text {th }}$ \\
\hline 4 & Conflicts resolution & $713(38 \%)$ & $806(43 \%)$ & $217(12 \%)$ & $93(5 \%)$ & $31(2 \%)$ & 4.91 & $5^{\text {th }}$ \\
\hline 5 & $\begin{array}{l}\text { Apportioning blames and } \\
\text { arbitrary words of mouth among } \\
\text { the stakeholders }\end{array}$ & $775(42 \%)$ & $868(47 \%)$ & $124(6 \%)$ & $93(5 \%)$ & 0 & 5.34 & $2^{\text {nd }}$ \\
\hline
\end{tabular}

Source: Field Survey, 2018

From the analysis in Table 2, it shows the extent of the impact of building collapse risks on the stakeholders under the following:

\subsection{Economic/Financial risks}

This has the following Mean Values: Loss of property -8.12 , Loss of materials -6.72 , Waste of resources, time and labour -6.64 , Loss of annual income/capital investment -6.37 , Cost of rebuilding/repair -6.09 , etc. The above analysis implies that the most predominant economic/financial risks that affect the stakeholders in the Nigerian built environment are: Loss of property $\left(1^{\text {st }}\right)$, loss of materials $\left(2^{\text {nd }}\right)$, waste of resources, time and labour $\left(3^{\text {rd }}\right)$.

\subsection{Socio-Political Risks}

The degree of the impact on the stakeholders has the mean values of: Loss of reputation and integrity of the contractors - 7.92, Psychological Trauma and shocks - 6.68, Professionals' marketability to foreign firms/clients are devalued -6.55 , Loss of trust -6.31 ,
Portrays the Nigerian Building Industry as being corrupt - 5.83, etc. The implication of the above analysis is that the most significant socio-political risks that impact on the stakeholders in the Nigerian built environment are: loss of reputation and integrity of the contractors $\left(1^{\text {st }}\right)$, Psychological trauma and shocks $\left(2^{\text {nd }}\right)$ and professionals' marketability to foreign firms/clients are devalued $\left(3^{\text {rd }}\right)$.

\subsection{Human Related Risks}

The sub-risks factors and their impact on the stakeholders are rated as follows: Loss of lives - 7.64, Injuries - 7.00, Psychological damage (fear, helplessness, distress, depression and suicides) 6.44 , Leads victims to permanent disability -5.89 , Disruption of Economic activities - 5.31, etc. From the analysis above, the most human related risks that affect the stakeholders in the Nigerian built environment are: loss of lives $\left(1^{\text {st }}\right)$, Injuries $\left(2^{\text {nd }}\right)$, Psychological damage $\left(3^{\text {rd }}\right)$ and Leads victims to permanent disability $\left(4^{\text {th }}\right)$. 


\subsection{Environmental risks}

The extent of the impact of environmental risks on the stakeholders are as follows: Place of abode for dangerous animals like snakes -6.02 , Degrading of the environment - 5.78, Environmental damage 5.70, Provides hideouts for robbers and hoodlums 5.51 , Loss of building aesthetics' values - 5.31, etc. The above table shows that the most significant environmental risks that impact on the stakeholders in the Nigerian built environment are: place of abode for dangerous animals like snakes $\left(1^{\text {st }}\right)$, degrading of the environment $\left(2^{\text {nd }}\right)$, environmental damage $\left(3^{\text {rd }}\right)$ and provides hideouts for robbers and hoodlums $\left(4^{\text {th }}\right)$.

\subsection{Physical Risks}

The following physical risks impact on the stakeholders as follows: Structural damage - 6.72, Damage of contents - 5.31, Replacement/repair of structure 5.28 , Loss of strength of the building -5.24 , Loss of functionality -5.20 , etc. The above analysis shows the most predominant physical risks that affect the stakeholders in the Nigerian built environment and they are: structural damage $\left(1^{\text {st }}\right)$, damage of contents $\left(2^{\text {nd }}\right)$ and replacement/repair of structure $\left(3^{\text {rd }}\right)$.

\subsection{Law/Legal Risks}

The impact on the stakeholders are: Legal tussle among the stakeholders -5.45 , Apportioning of blame and arbitrary words of mouth among the stakeholders -5.34 , Exasperation of crises among the stakeholders - 5.20, Arbitration/Mediation to resolve crises arising from building collapse -5.15 and Conflicts resolution 4.91. The analysis of law/legal risks above shows that the most predominant factors that affect the stakeholders in the Nigerian built environment are: legal tussle among the stakeholders $\left(1^{\text {st }}\right)$, apportioning of blame and arbitrary words of mouth among the stakeholders $\left(2^{\text {nd }}\right)$ and Exasperation of crises among the stakeholders $\left(3^{\text {rd }}\right)$. It could be deduced from the above analysis that economic/financial risks have the predominant impact on the stakeholders, followed by Human related risks, Socio-Political risks, Physical risks, Environmental risks and lastly Law/Legal risks.

\section{CONCLUSION AND RECOMMENDATIONS:}

The study evaluates the effects of building collapse risks on the stakeholders in the Nigerian built environment and the specific objectives attained. The aim and objectives of the study were achieved through the analysis of the views of the stakeholders in the built environment, professionals, clients/developers and users of the finished product. From the study carried out, it is evident that building collapse risks exist in the Nigerian environment. These building collapse risks have multifarious factors which were categorized as Economic/Financials risk factors, SocioPolitical risk factors, Human related risk factors, Physical risk factors, Environmental risk factors and Law/legal risk factors. The negative effects of these risks are: loss of property, loss of reputation and integrity of the contractors, loss of lives, legal tussle among the stakeholders, etc. It was also found out that economic/financial risks have the predominant effect on the stakeholders, followed by Human related risks, Socio-Political risks, Physical risks, Environmental risks, while law/legal risk factors have the least effect. It was recommended that all hands should be on deck to curb the havoc caused by the building collapse as the effect is usually felt by all and sundry. There should be adequate funding and monitoring of the activities of all emergency agencies such as National Emergency Management Agency (NEMA), State Emergency Management Agency (SEMA), Local Emergency Management Agency (LEMA), Red Cross Society, Nigeria Fire Service, and NGOs among others.

\section{REFERENCES}

[1] Bala, K. "Building Collapse in Nigeria: Challenges and Remediation". $11^{\text {th }}$ Annual Lecture/ Conference. Faculty of Environmental Sciences, Nnamdi Azikiwe University, Awka, Nigeria. $5^{\text {th }}-$ $7^{\text {th }}$ June, 2017.

[2] Akande, B.F, Debo-Saiye, B., Alao, T.O \& Akinrogunde, O.O. "Cause, Effects and Remedies to Incessant Building Collapse in Lagos State". International Journal of Basic and Applied Sciences. Vol. 16, No. 4, 2016, pp.15- 30.

[3] Ayedun, C. A., Durodola, O. D \&Akinjare, O. A. "An Empirical Ascertainment of the Causes of Building Failure and Collapse in Nigeria". Mediterranean Journal of Social Sciences. Vol. 3, No. 1, 2012, pp. $313-322$.

[4] Windapo, A. O. \& Rotimi, J. O. "Contemporary Issues in Building Collapse and Its Implications for Sustainable Development". Buildings. www.mdpi.com/journal/buildings, Accessed July 15, 2015.

[5] CORBON. Submissions of Council of Registered Builders of Nigeria on the Building Collapse in Nigeria submitted to the Senate Committee on Housing, 2016. 
[6] Adedeji, J.A. "Environmental Disasters and Management: Case study of Building Collapse in Nigeria". International Journal of Construction Engineering and Management. Vol. 2, No. 3, 2013, pp. $39-45$.

[7] Ede, A. N. "Building Collapse in Nigeria: The trend of casualties in the last decade (2000 - 2010)". International Journal of Civil \& Environmental Engineering, Vol. 10, No. , 2013, pp. $32-36$.

[8] Oke, A. "An Examination of the Causes and Effects of Building Collapse in Nigeria". Journal of Design and Built Environment. Vol. 9, No. , 2011, pp. 37 $-47$.

[9] Nwafor, A.U. "Building Failures/ Collapses and their Reputational Effect on Building Industry in Nigeria". International Journal of Science and Research (IJSR). Vol. 4, No. 6, 2015, pp. 847 853.

[10] Dimuna, K. O. "Incessant Incidents of Building Collapse in Nigeria: A Challenge to Stakeholders".
Global Journal of Research in Engineering. Vol. 10, No. 4, 2010, pp. $75-84$.

[11] Olumide, A.A. "Professionals in the Built Environment and Incidences of Building Collapse in Nigeria". Organisation, Technology and Management in Construction - An International Journal. Vol. 4, No. 2, 2012, pp. $461-475$.

[12] Adebowale, P. A., Gambo, M. D., Ankeli, I. A., \& Daniel, I. D. "Building Collapse in Nigeria: Issues and Challenges". Proceedings of the International Journal of Art and Sciences. 2016, pp. 99-108.

[13] Chendo, I.G and Obi, N.I. "Building collapse in Nigeria: The causes, effects, consequences and remedies". International Journal of Civil Engineering Construction and Estate Management. Vol. 3, No. 4, 2015, pp. 41 - 49.

[14] Janssens, V., Dermot, W.O \& Marios, K.C. "Building Failure Consequences". Robustness of Structures. Proceedings of the final conference of COST Action TU0601. 2010. 